\title{
Suppression of annual bromes impacts rangeland: Animal responses
}

\author{
MARSHALL R. HAFERKAMP, ELAINE E. GRINGS, R.K. HEITSCHMIDT, MICHAEL D. MacNEIL, \\ AND MICHAEL G. KARL
}

Authors are rangeland scientist, research animal scientist, supervisory rangeland scientist, research geneticist, and postdoctoral rangeland scientist USDA-ARS, Fort Keogh Livestock and Range Research Laboratory, Miles City, Mont. 59301. Karl is currently rangeland management specialist, USDI-Bureau of Land Management, Washington, DC 20240.

\section{Abstract}

Presence of annual bromes (Bromus spp.), introduced annual weedy grasses, can alter seasonal patterns of forage production and quality and require management changes for efficient use of infested rangelands. We determined biological impacts of the presence of brome by comparing livestock performance on brome infested rangeland to similar sites on which brome had been suppressed by autumn application of atrazine [6-chloro-Nethyl-N'-(1-methylethyl)-1,3,5-triazine-2,4-diamine] at $0.56 \mathrm{~kg}$ $\mathrm{ha}^{-1}$ in 1992 and 1993. Each treatment was randomly assigned to three, 12-ha pastures. Vegetation was measured for 5 months (May to September) each year from 1993 to 1995. Each pasture was stocked with 8 crossbred steers of British breed origin (Bos taurus) from mid-May to mid-September 1993 and 1995 and to mid-August 1994. Initial body weights averaged $329 \mathrm{~kg} \mathrm{SD}=31$ in 1993, $273 \mathrm{~kg} \mathrm{SD}=14$ in 1994, and $272 \mathrm{~kg} \mathrm{SD}=21$ in 1995. Brome suppression and environment influenced plant species in diets, diet quality, and livestock performance. Brome suppression reduced percentage of annual grasses in diets from $14 \%$ to $10 \%$. Annual grasses were replaced in the diet by a variety of forb and grass species \{western wheatgrass [Pascopyrum smithii Rydb. (Love)], and blue grama [Bouteloua gracilis [H.B.K.] Lag. ex Griffiths]\}, with specific replacement depending on year and month. Steer gains were increased from 0.92 to $1.04 \pm 0.02 \mathrm{~kg}$ head $^{-1}$ day $^{-1}(\mathrm{P}<0.02)$ and from 69 to $81 \pm 2.8 \mathrm{~kg} \mathrm{ha}^{-1}(\mathrm{P}<0.05)$ with brome suppression. This experiment demonstrated that improvement in livestock performance can be expected with the suppression of annual bromes on semiarid rangelands.

Key Words: Bromus japonicus, Pascopyrum smithii, Northern Great Plains, crude protein yield

Annual bromes (Bromus spp.) have infested thousands of hectares of Northern Great Plains rangelands (Haferkamp et al. 1993, Whisenant 1990, Hewlett et al. 1981). Annual bromes affect associated plant species and nutritional quality of herbage

The authors express appreciation to Bryon Bennett, Caralee Leidholt, Chery Murphy, Duane Bundy, and several summer aids for field assistance, and Mary Ellen French and Diona Austill for assistance with graphics.

This paper is a contribution from the USDA-ARS and Montana Agr. Exp. Sta. Miles City, Mont.

The USDA-ARS, Northern Plains Area, is an equal opportunity/affirmative action employer, and all agency services are available without discrimination.

Manuscript accepted Jan. 27, 01

\section{Resumen}

La presencia de "Bromos" anuales invasores (Bromus spp.) puede alterar los patrones estacionales de producción y calidad de forraje y requieren cambios de manejo para hacer un uso eficiente de los pastizales infestados de las Grandes Planicies del Norte. Estudiamos los impactos biológicos de la presencia del "Bromo" mediante la comparación de pastizales infestados con sitios similares en los cuales el "Bromo" había sido suprimido con aplicaciones en otoño de atrazina [6-cloro-N-etil-N'-(1metiletil)-1,3,5-triazina-2,4-diamina] en dosis de $0.56 \mathrm{~kg} \mathrm{ha}^{-1}$ efectuadas en 1992 y 1993. Cada tratamiento se asignó aleatoriamente a tres potreros de 12 ha. De 1993 a 1995 la vegetación se midió anualmente durante 5 meses (Mayo a Septiembre). En 1993 y 1995, de mediados de Mayo a mediados de Septiembre, cada potrero se cargó con 8 novillos de cruzas comerciales (Bos taurus) y en 1994 se utilizaron hasta mediados de Agosto. El forraje base varió temporalmente por fecha y año, pero generalmente no fue menor de $800 \mathrm{~kg} \mathrm{ha}^{-1}$. La supresión de "Bromo" incrementó $(P<0.05)$ la concentración de proteína cruda del "Western wheatgrass" (Pascopyrum smithii Rydb. [Love]) en Julio (7.1 vs. 9.1\%) y Agosto (6.0 vs. $7.1 \%)$. Con la variación entre años de las poblaciones de "Bromo", por influencia de las condiciones durante el período de crecimiento, este experimento demostró que al suprimir el "Bromo" anual se puede esperar un mejoramiento en la calidad nutricional de los pastizales semiáridos.

available to grazing livestock (Haferkamp et al. 1994, 1997, 1998). The major characteristics of annual bromes affecting livestock management decisions include erratic fluctuations in annual forage production (Haferkamp et al. 2001, Haferkamp et al. 1993, Gartner et al. 1986), reduction in perennial plant production (Haferkamp et al. 1997, 1998, Rummell 1946), and early plant maturation (Haferkamp et al. 1994, Vallentine and Stevens 1994). Although early spring and autumn grazing are proposed as the best ways to use annual brome infested ranges (Mayland et al. 1994, Tipton 1994, Vallentine and Stevens 1994), some of these ranges must be used during the summer when forage nutritional quality of annual bromes may suppress livestock performance (Heitschmidt et al. 1993, Currie et al. 1989). The objective of this study was to test the hypothesis that summer rates of gain of steers grazing Northern Great Plains ranges infested with annual bromes would be less than gains of steers grazing adjacent ranges where annual brome abundance was suppressed. 


\section{Materials and Methods}

\section{Study Site}

Research was conducted at the Fort Keogh Livestock and Range Research Laboratory $\left(46^{\circ} 22^{\prime} \mathrm{N} 105^{\circ} 5^{\prime} \mathrm{W}\right)$ near Miles City, Mont. Elevation ranges from 716 to $853 \mathrm{~m}$. Regional topography ranges from rolling hills to broken badlands with small intersecting ephemeral streams flowing into rivers in broad, nearly level valleys. Annual precipitation averages $343 \mathrm{~mm}$, with about $60 \%$ received from April through September. Daily temperatures range from $>38^{\circ} \mathrm{C}$ during summer to $<-40^{\circ} \mathrm{C}$ during winter. The average frost-free growing season is 150 days. Indigenous vegetation on the 22,500-ha research station is a

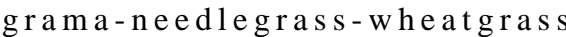
(Bouteloua-Stipa-Agropyron) mix (Kuchler 1964).

Soils at the specific-study site are a composite of Absher heavy clays (Fine, smectitic, frigid Leptic Torrertic Natrustalfs) and Gerdrum silty clay loams (Fine, smectitic, frigid Torretic Natrustalfs). Topography is gently sloping $(<2 \%)$. Vegetation is dominated by western wheatgrass (Pascopyrum smithii Rydb. [Love]), blue grama (Bouteloua gracilis [H.B.K.] Lag. ex Griffiths), Sandberg bluegrass (Poa secunda Presl.), sand dropseed (Sporobolus cryptandrus [Torr.] Gray), and Japanese brome (Bromus japonicus Thunb.). Threadleaf sedge (Carex filifolia Nutt.) is the dominant grasslike species. Dandelion (Taraxacum officinale Weber) and salsify (Tragopogon dubius Scop.) are the dominant forb species.

\section{Treatments and Experimental Design}

Six, 12-ha pastures were used in this study (Haferkamp et al. 2001). The 2 treatments (brome suppression and control) were assigned randomly to 6 pastures in a completely random design. Pasture was the experimental unit. Brome was suppressed with atrazine [6-chloro-N-ethylN'-(1-methylethyl)-1,3,5-triazine-2,4diamine] applied to dormant vegetation in November 1992 and 1993 at $0.56 \mathrm{~kg}$ a.i. $\mathrm{ha}^{-1}$. Herbicide was applied by ground in 1992 in 150 liters water ha ${ }^{-1}$ and by air in 1993 in 19 liters water ha ${ }^{-1}$. No herbicide was applied in autumn 1994.

\section{Livestock Sampling}

Each treatment was stocked annually with 8 crossbred yearling steers of British breed origin (Bos taurus) per 12-ha pasture. Pastures were stocked continuously from mid-May until mid-September 1993 and 1995. Limited forage production in 1994 resulted in a shortened grazing season extending from mid-May to midAugust. Steers were handled according to protocol approved by the Fort Keogh Livestock and Range Research Laboratory Animal Care Committee.

At the beginning of each grazing season steers were weighed. Steers were stratified by initial weight and within strata randomly assigned to pastures. Thereafter, weights were obtained about every 30 days, and at the end of each annual trial. Duration of the periods between sampling dates ranged from 23 to 37 days. Average daily gains were calculated from the weights taken at adjacent sampling dates and the duration of the respective period. Total gain was average daily gain multiplied times number of steers in the pasture and the number of days in the period. Gain per hectare was total gain divided by the area of the pasture. Shrunk weights on and off pastures were initiated in 1994 due to scale malfunction. Steers received a 200day estradiol implant in early May 1994 and 1995 , but not 1993 . Steers were treated with Ivermectin ${ }^{1}$ (Merck \& Co. Inc., Whitehouse Station, N.J.) before the study for parasite control and received a Python ${ }^{1}$ fly repellent ear tag (Y-TEX Corp., Cody, Wyo.) at the beginning of the grazing season. Steers were allowed ad libitum access to a loose trace mineralized salt mix containing $36 \% \mathrm{Cl}, 24 \% \mathrm{Na}, 6 \% \mathrm{P}, 5 \% \mathrm{Ca}$, 240 ppm Zn, 240 ppm Mn, 60 ppm Cu, 9 ppm I, 3 ppm Co, 0.9 ppm Se, 8800 IU vit$\operatorname{amin} \mathrm{A} \mathrm{kg}^{-1}$, and $880 \mathrm{IU}$ vitamin $\mathrm{D} \mathrm{kg}^{-1}$.

Diet quality was sampled monthly in all treatments during the week steers were weighed. Six to 8 esophageally cannulated crossbred heifers were used for diet sample collection. Diets were collected from at least 3 heifers per pasture, and not all pastures were sampled with the same heifers. Heifers were penned at 1600 hours with water but no feed available. Collections were made the following morning beginning at 0700 hours. Collection periods lasted from 20 to 30 min and were followed immediately by a collection in a second pasture. Esophageal masticate samples were thoroughly mixed by hand, freeze dried, and subsampled for diet quality and diet composition analyses. Sample collections began when these heifers were about 15 months of age.

\footnotetext{
${ }^{1}$ Mention of a trade name or a specific proprietary product does not constitute a guarantee or warranty by the authors or USDA-ARS nor does it imply the approval of these products to the exclusion of others.
}

Heifers had been cannulated at 2 months of age and were experienced with the diet collection process. Estrous was suppressed during diet collection periods by the use of a Norgestomet ${ }^{1}$ implant (Sanofi Animal Health, Overland Park, Kan.). Between sampling periods, heifers were kept in larger pastures with a variety of range sites. Heifers had been previously exposed to all plant species present in the experimental pastures.

\section{Laboratory Analysis}

Esophageal masticate and standing crop samples (Haferkamp et al. 2001) were ground to pass through a 1-mm screen in a Wiley mill ${ }^{1}$ (Arthur H. Thomas Co., Philadelphia, Penn.). Total nitrogen (N; organic matter basis) was determined with a Technicon ${ }^{1}$ Auto Analyzer (Technicon Industrial Systems 1977, Tarrytown, N.Y.). Data are presented as percentage crude protein (CP; percentage $\mathrm{N}^{*} 6.25$ ) and $C P$ yield (standing crop*decimal equivalent $\mathrm{CP}$ ). In vitro digestible organic matter (IVDOM) was determined using a modified Tilley and Terry (1963) technique (White et al. 1981).

Diet composition by plant species was determined using a point-frame technique on unground samples of lyophilized tissue (Angell et al. 1986). The fragment hit at each point was identified and recorded. If no hit occurred, the closest fragment to the pin point in a forward 180-degree arc was used. Each sample was assessed at 100 points.

\section{Data Summarization and Analysis}

Analysis of variance was used to test effects of treatments, years, dates, and interactions among them. Treatment effects were tested with the residual variation among pastures within treatment, and years and the year by treatment interaction were tested with the year by pasture within treatment interaction. Effects of dates and interactions of dates with other effects were tested with the residual variation after accounting for all other effects in the model.

Data for the fourth sampling period in 1994 were missing, thus the marginal means for treatment were non-estimable. However, treatment by period subclass means were estimable. Means were compared using the Least Significant Difference method protected by a significant F-statistic $(\mathrm{P} \leq 0.05)$ from the analysis of variance (SAS 1990).

Comparisons for CP yield were limited to May, June, July, and August, due to the 
lack of September samples in 1994. Most analyses were run on the following species groups: Western wheatgrass + Sandberg bluegrass, other perennial grasses, annual grasses, sedges, forbs, total green biomass, standing dead, and total biomass.

\section{Results and Discussion}

\section{Brome Suppression \\ Standing Crop}

Impact of brome suppression on standing crop ( $\mathrm{kg} \mathrm{DM} \mathrm{ha}{ }^{-1}$ ) and forage nutritive value have been reported previously (Haferkamp et al. 2001). Findings showed annual brome suppression with atrazine had the following effects: decreased standing crop of annual grasses $(\mathrm{P} \leq 0.05)$, total vegetation $(\mathrm{P} \leq 0.05$ for year by treatment by date interaction), and total vegetation plus standing dead ( $\mathrm{P} \leq 0.05$ for year by treatment by date interaction) and increased forage nutritive value of western wheatgrass $(\mathrm{P} \leq 0.05)$ and Japanese brome $(\mathrm{P} \leq 0.05)$ as indicated by increases in CP. Significant interactions with date and year showed that these responses would vary with the changing environmental conditions both within and across years.

\section{Crude Protein Yield}

Animal performance can be limited by either forage quality or quantity. Total yield of nutrients is an important way to evaluate treatment effects for their potential to impact animal gains. Crude protein yields $\left(\mathrm{kg} \mathrm{CP} \mathrm{ha}^{-1}\right)$ of annual grasses were somewhat constant among dates and years when brome was suppressed, but yields varied among dates and years with brome present (Fig. 1A and B). Magnitude of treatment differences declined from spring to late summer (Fig. 1A). Crude protein yield of annual grass was increased $(\mathrm{P} \leq$ $0.01)$ by presence of bromes in 1993 and 1995, but not 1994 (Fig. 1B).

\section{Steer Diets}

Brome suppression decreased percentage of annual grasses in the diet from $14 \%$ to $10 \%(\mathrm{P} \leq 0.01)$. The dietary proportion of other perennial grass was reduced by brome suppression in May and August but not June or July (Table 1). With brome suppression, much of the dietary annual grasses were replaced by western wheatgrass even though brome suppression did not affect the western wheatgrass + Sandberg bluegrass group, the dominant component of steer diets (57\%). There was also some replacement by forbs and blue

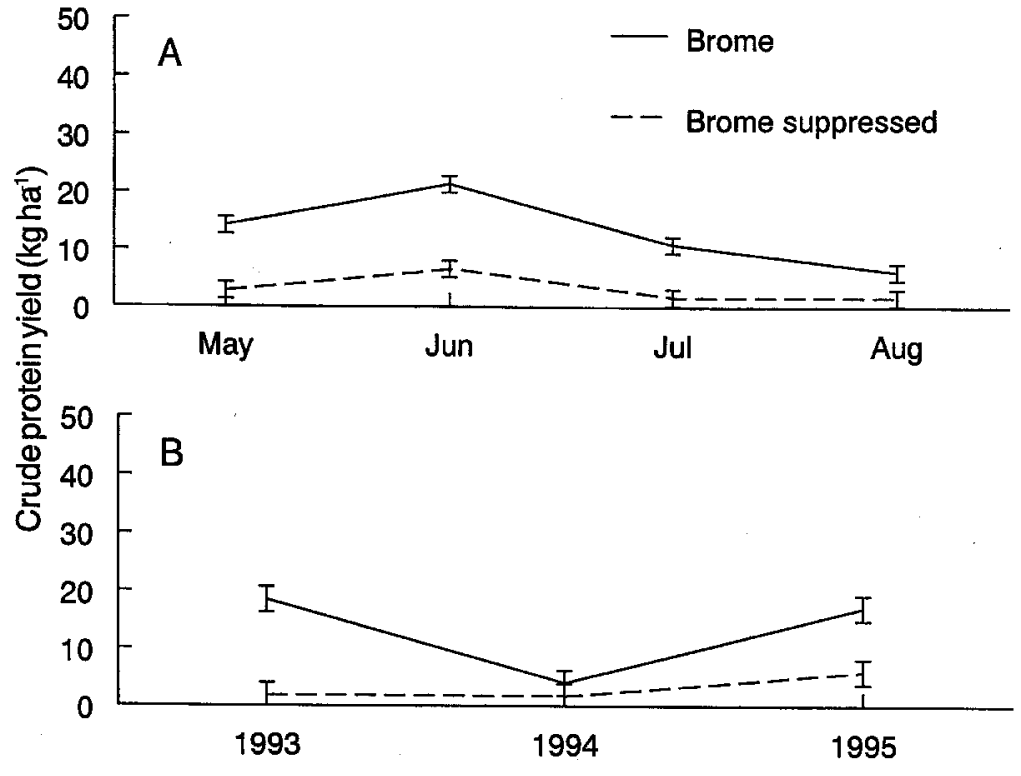

Fig. 1. Least-square-means and standard errors for CP yield ( $\mathrm{kg} \mathrm{ha}^{-1}$ ) for significant (A) date by brome suppression $(\mathrm{P} \leq \mathrm{0.01})$ and $(\mathrm{B})$ year by brome suppression interactions for annual grasses $(\mathbf{P} \leq \mathbf{0 . 0 1})$.

grama at various times. Specific replacement depended upon year and month.

Neither diet CP concentration $(13.3 \%)$ nor IVDOM $(68.5 \%)$ was affected by brome suppression. Moreover no interactions with treatment affecting diet quality were significant.

\section{Steer Gains}

Initial weight of steers averaged $329 \mathrm{~kg}$ $(\mathrm{SD}=31)$ in $1993,273 \mathrm{~kg}(\mathrm{SD}=14)$ in 1994 (12-hour with water shrunk weight), and $272 \mathrm{~kg}(\mathrm{SD}=21)$ in 1995 . Steer average daily gains during the May to September grazing season were increased ( $\mathrm{P} \leq 0.05)$ from 0.92 to $1.04 \pm 0.02 \mathrm{~kg}$ head $^{-1}$ day $^{-1}$, and gains per hectare were increased $(\mathrm{P} \leq 0.05)$ from 69 to $81 \pm 2.8$ $\mathrm{kg} \mathrm{ha}^{-1}$ by brome suppression. The treatment by year interaction was not significant for steer gains. Hart et al. (1995) reported that with put and take stocking, atrazine tended to increase carrying capacity and gain $\mathrm{ha}^{-1}$, but not average daily gain

Table 1. Least-square-means and SE for date by brome suppression treatment interaction for percentage of other perennial grass component in steer diets.

\begin{tabular}{|c|c|c|c|c|}
\hline \multirow{2}{*}{$\begin{array}{l}\text { Brome } \\
\text { treatment }\end{array}$} & \multicolumn{4}{|c|}{ Date } \\
\hline & May & June & July & August \\
\hline & \multicolumn{4}{|c|}{ 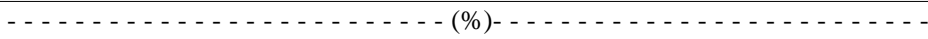 } \\
\hline Undisturbed & $17^{\mathrm{BCa} 1}$ & $12^{\mathrm{Ca}}$ & $18^{\mathrm{Ba}}$ & $25^{\mathrm{Aa}}$ \\
\hline Suppressed & $11^{\mathrm{Cb}}$ & $15^{\mathrm{BCa}}$ & $24^{\mathrm{Aa}}$ & $19^{\mathrm{ABb}}$ \\
\hline SE & \multicolumn{4}{|c|}{1.9} \\
\hline
\end{tabular}

${ }^{1}$ Comparison of date effect for each brome suppression treatment (within a row) is indicated by uppercase superscripts. Comparison of treatment effect for each date (within a column) is indicated by lowercase superscripts. Means with similar superscripts are not significantly different $(\mathrm{P} \leq 0.05)$. or average returns to land, labor, or management on blue grama dominated range in eastern Colorado. They suggested that with optimum stocking rates, atrazine might increase returns (heavy stocking early in the season and lighter stocking later).

\section{Environmental Effects \\ Crude Protein Yield}

Crude protein yields of annual grasses were greater with brome in the wetter years of 1993 and 1995 than in 1994 (Fig. 1B). Crude protein yields varied significantly among dates within years for western wheatgrass + Sandberg bluegrass (Fig. 2A), other perennial grasses (data not shown), standing dead (Fig. 2B), and total vegetation (Fig. 2C). The dominance of western wheatgrass in this plant community is clearly shown by the similarity of $\mathrm{CP}$ yield between western wheatgrass + Sandberg bluegrass (Fig. 2A) and total vegetation (Fig. 2C). Crude protein yield of standing dead (Fig. 2B) averaged $6.3 \mathrm{~kg}$ 


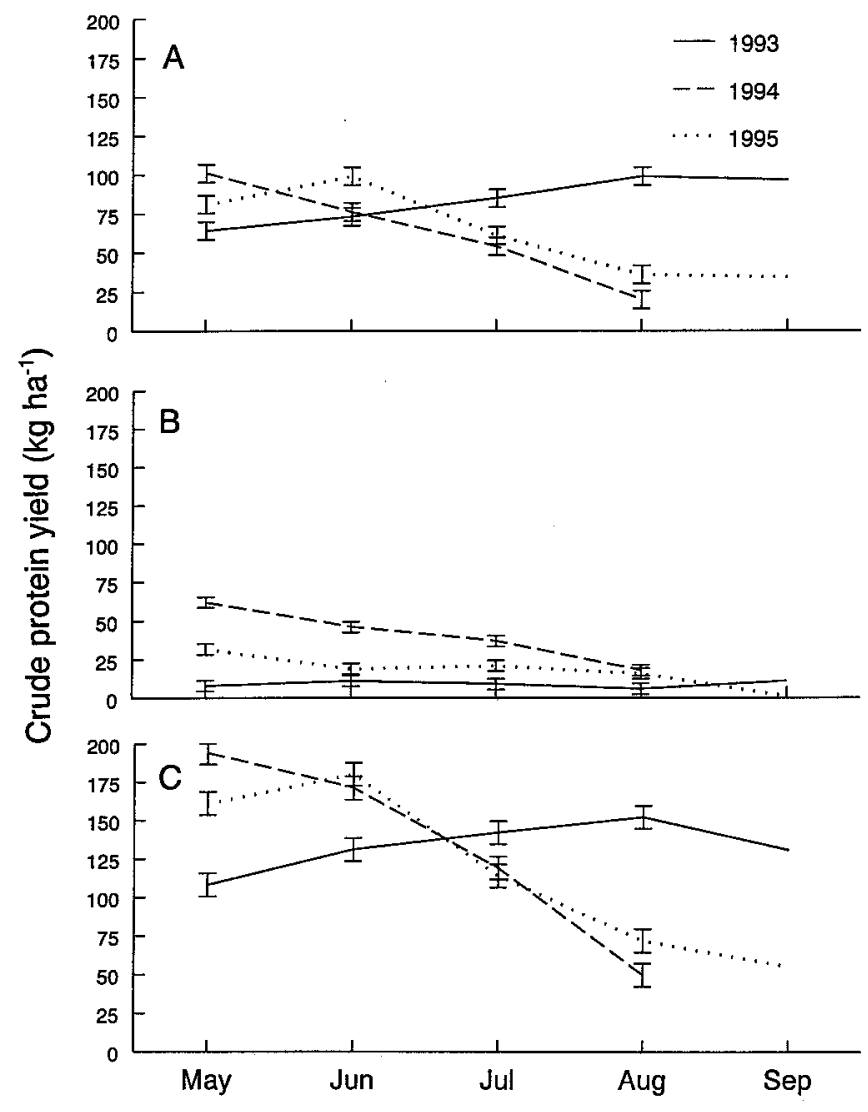

Fig. 2. Least-square-means and standard errors for $\mathrm{CP}$ yield $\left(\mathrm{kg} \mathrm{ha}^{-1}\right)$ for significant year by date interaction for (A) western wheatgrass + Sandberg bluegrass $(P \leq 0.01),(B)$ standing dead $(P \leq$ $0.01)$, and $(C)$ total biomass $(P \leq 0.01)$. September data for 1993 and 1995 are included for visual comparisons, but these data were not included in statistical analyses.

$\mathrm{ha}^{-1}$ among dates and changed little in 1993, but decreased 44 and $16 \mathrm{~kg} \mathrm{ha}^{-1}$ with advancing date in 1994 and 1995. The relatively small CP yield for standing dead in
1993 was partially related to grazing standing crop to a short stubble in late summer 1992 prior to applying atrazine. In contrast ample precipitation produced

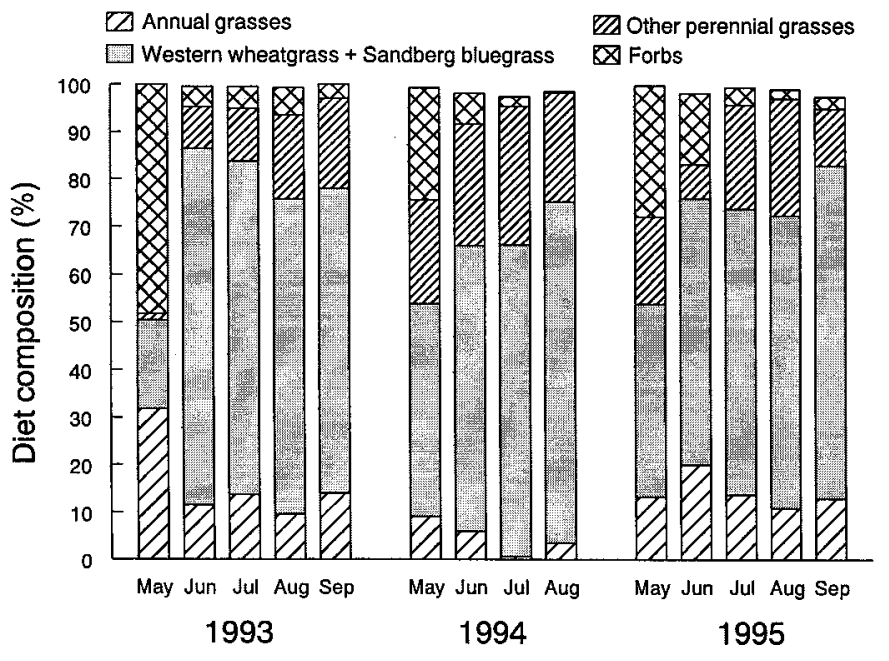

Fig. 3. Least-square-means for percentage diet composition for significant $(P \leq 0.05)$ year by date interactions. September data for 1993 and 1995 are included for visual comparisons, but these data were not included in statistical analyses. large amounts of herbage in 1993 that was converted to standing dead in 1994. An intermediate amount of herbage was converted to standing dead in 1995.

\section{Steer Diets}

Percentages of plant species groups contained in steer diets varied with date among year (Fig. 3). Maximum proportions of annual grasses in the diet occurred in May 1993. Although dietary content of annual grasses declined $(\mathrm{P} \leq 0.01)$ from May to June 1993, percentages were similar among remaining dates in 1993 and all dates in 1994 and 1995. In addition to May, distinct year differences were also noted in July when only $1 \%$ annual grass was present in diets in 1994 compared with $14 \%$ in 1993 and 1995. This is a reflection of the small amount of annual grass available in the 1994 standing crop (<30 kg ha $\left.{ }^{-1}\right)$. Cool-season perennial grasses (western wheatgrass and Sandberg bluegrass $)$ in the diet increased $(\mathrm{P} \leq 0.01)$ from May each year, with dietary proportions being similar during the remainder of the grazing season. The amount of other perennial grasses in the diet increased $(\mathrm{P} \leq$ 0.01) from May 1993, but differences among dates were not as distinct in 1994 and 1995.

In 1993, CP concentration in diets declined from May to July but increased in August to levels similar to June (Fig. 4B). Crude protein of diets declined from May to August in 1994 and 1995. Digestibility decreased with advancing date each year (Fig. 4A). The year differences, higher quality in 1993, clearly show the influence of growing-season precipitation on diet quality.

\section{Steer Gains}

Most of the variation in steer gains exhibited in Table 2 can be explained by utilization of shrunk weight on and off pastures in 1994 and previously described variation in amount and distribution of precipitation and the subsequent impact on the quantity and nutritional quality of forage (Haferkamp et al. 2001). Average daily gains were consistently greater in the first half than the second half of the grazing season, and due to the shrink, gains decreased more rapidly in the 1994 season than in the wetter 1993 and 1995 seasons (Table 2). May to June daily gains were least in 1993 when May precipitation was below average, whereas 1993 late season gains were highest or equal to gains in 1995 in response to cool temperatures and above average precipitation. Gain aver- 
Table 2. Least-square-means and SE for significant year by date interaction for steer gains and average duration of each grazing period.

\begin{tabular}{|c|c|c|c|c|}
\hline \multirow[t]{2}{*}{ Year } & \multicolumn{4}{|c|}{ Date and average length of grazing periods } \\
\hline & $\begin{array}{l}\text { May } \\
\text { June } \\
\text { (25 days) }\end{array}$ & $\begin{array}{l}\text { June } \\
\text { July } \\
\text { (30 days) }\end{array}$ & $\begin{array}{l}\text { July } \\
\text { August } \\
\text { (33.3 days) }\end{array}$ & $\begin{array}{l}\text { August } \\
\text { September } \\
\text { (34.5 days) }\end{array}$ \\
\hline & \multicolumn{4}{|c|}{$\ldots \ldots\left(\mathrm{kg} \mathrm{head}^{-1} \mathrm{day}^{-1}\right) \ldots \ldots$} \\
\hline 1993 & $1.41^{\mathrm{Ac}}$ & $1.38^{\mathrm{Aa}}$ & $0.79^{\mathrm{Ba}}$ & $0.61^{\mathrm{Ca}}$ \\
\hline 1994 & $2.05^{\mathrm{Aa}}$ & $1.17^{\mathrm{Bb}}$ & $0.27^{\mathrm{Cb}}$ & - \\
\hline 1995 & $1.86^{\mathrm{Ab}}$ & $1.19^{\mathrm{Bb}}$ & $0.80^{\mathrm{Ca}}$ & $0.29^{\mathrm{Db}}$ \\
\hline SE & \multicolumn{4}{|c|}{0.06} \\
\hline
\end{tabular}

${ }^{T}$ Comparison of year effect for each grazing period (within a row) is indicated by upper case superscripts. Comparison of date effect for each year (within a column) is indicated by lower case superscripts. Means with similar superscripts are not significantly different $(\mathrm{P} \leq 0.05)$.

aged $82 \mathrm{~kg} \mathrm{ha}^{-1}$ in 1993 and 1995 but was less $(\mathrm{P} \leq 0.01)$ in $1994\left(60 \mathrm{~kg} \mathrm{ha}^{-1}\right)$ due to the truncated grazing season. This difference $(\mathrm{P} \leq 0.01)$ was shown in the May to August gain data collected for the 3 years. May to August gains averaged $70 \pm 1.3 \mathrm{~kg}$ $\mathrm{ha}^{-1}$ in $1993,60 \pm 1.3 \mathrm{~kg} \mathrm{ha}^{-1}$ in 1994 , and $74 \pm 1.3 \mathrm{~kg} \mathrm{ha}^{-1}$ in 1995 . Daily gains were similar to those reported by Grings et al. (1996) for steers grazing other pastures at Fort Keogh during the same time period. They found steers gained from 1.3 to 1.5 $\mathrm{kg} \mathrm{head}^{-1}$ day $^{-1}$ during May to September 1993, May to July 1994, and May to August 1995. In contrast, steers gained 0.6 to $1 \mathrm{~kg} \mathrm{head}^{-1} \mathrm{day}^{-1}$ when grazing September to October 1993, July to September 1994, and August to September 1995

\section{Conclusions}

Findings reported here and in Haferkamp et al. (2001) show annual brome suppression with atrazine has the following effects: decreased standing crops of annual grasses, total vegetation and total vegetation plus standing dead; increased forage nutritive value of western wheatgrass and Japanese brome; and decreased proportions of annual grasses and other perennial grasses in diets. Interactions with date and year suggest that these responses will vary with the changing environmental conditions both within and among years.

Gains of stocker cattle were increased about $16 \%$ by suppression of annual brome on Northern Great Plains ranges. The untreated pastures were uniformly

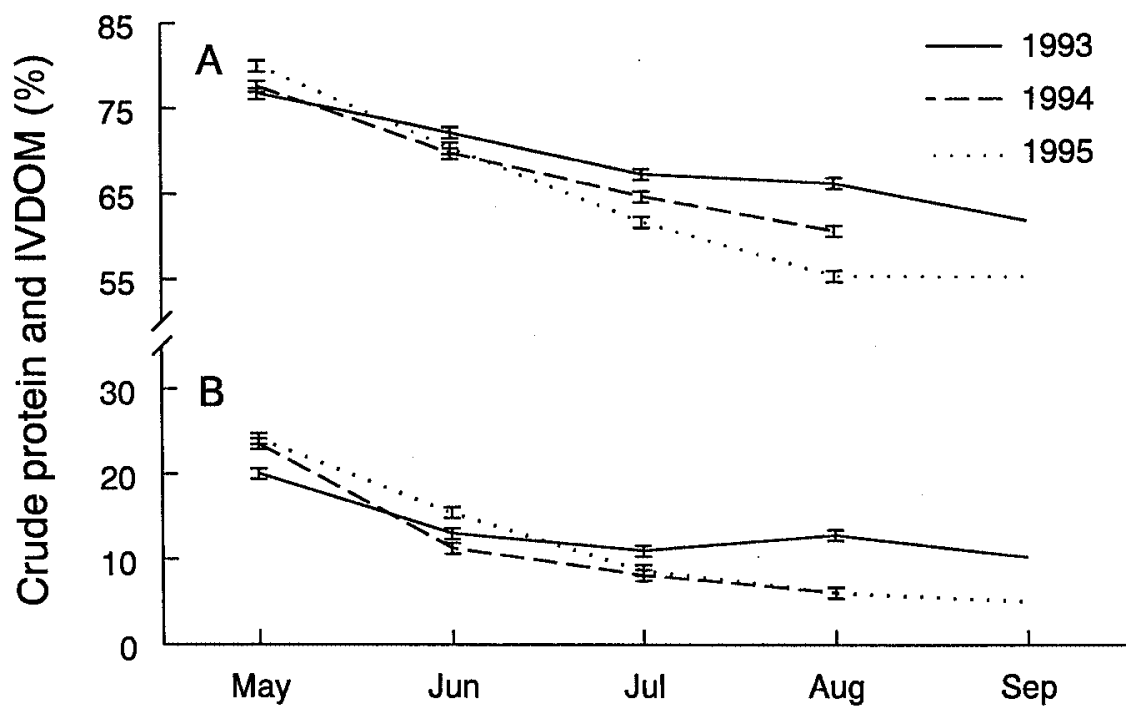

Fig. 4. Least-square-means and standard errors for percentage diet $\mathrm{CP}$ concentration $(\mathbf{P} \leq \mathbf{0 . 0 1})$ and percentage IVDOM $(P \leq \mathbf{0 . 0 1})$ for significant year by date interaction. September data for 1993 and 1995 are included for visual comparisons, but these data were not included in statistical analyses. infested by annual bromes, but standing crop of annual grasses was small relative to other years on this site (Haferkamp et al. 2001). Thus, the increase in livestock performance with annual brome suppression might be greater with larger brome standing crop or higher composition of annual bromes, but it might be smaller when steers graze large pastures with spotty distribution of annual bromes. The botanical composition of pastures used for summer grazing yearling cattle should be evaluated before devising management strategies to maximize efficiency of utilization of Northern Great Plains rangelands.

\section{Literature Cited}

Angell, R.F., J.W. Stuth, and D.L. Drawe. 1986. Diets and live weight changes of cattle grazing fall burned gulf cordgrass. J. Range Manage. 39:233-236.

Currie, P.O., J.D. Volesky, D.C. Adams, and B.W. Knapp. 1989. Growth patterns of yearling steers determined from daily live weights. J. Range Manage. 42:393--396.

Gartner, F.R., E.M. White, and R.I. Butterfield. 1986. Mechanical treatment and burning for high quality range forage, p.135-140. In: South Dakota Beef Report, Animal Range Sciences Dept., Agr. Exp. Sta., Coop. Ext. Serv., South Dakota State Univ., Brookings, S. Dak.

Grings, E.E., R.K. Heitschmidt, R.E. Short, B.S. Hould, and N.R. Bellows. 1996. Management strategies for grazing yearling cattle in the Northern Great Plains. Proc. West. Sec. Amer. Soc. Anim. Sci. 47(Suppl. 1): 145 .

Haferkamp, M.R., R.K. Heitschmidt, and M.G. Karl. 1997. Influence of Japanese brome on western wheatgrass yield. J. Range Manage. 50:44-50.

Haferkamp, M.R., R.K. Heitschmidt, and M.G. Karl. 1998. Clipping and Japanese brome reduce western wheatgrass standing crop. J. Range Manage. 51:692-698.

Haferkamp, M.R., R.K. Heitschmidt, E.E. Grings, M.D. MacNeil, and M.G. Karl. 2001. Suppression of annual bromes impacts rangeland: Vegetation responses. J. Range. Manage. 54:656-662.

Haferkamp, M.R., J.D. Volesky, M.M. Borman, R.K. Heitschmidt, and P.O. Currie. 1993. Effects of mechanical treatments and climatic factors on the productivity of Northern Great Plains rangelands. J. Range Manage. 46:346-350.

Haferkamp, M.R., J.A. Young, E.E. Grings, M.G. Karl, R.K. Heitschmidt, and M.D. MacNeil. 1994. Japanese brome in the Northern Great Plains, p.396-401. In: S.B. Monsen and S.G. Kitchen (eds.) Proc.Ecology and management of annual rangelands. 18-21 May 1992. Boise, Ida., USDAFS Gen. Tech. Rep. INT-GTR 313. Ogden, Ut. 
Hart, R.H., M.C. Shoop, and M.M. Ashby. 1995. Nitrogen and atrazine on shortgrass: Vegetation, cattle, and economic responses. J. Range Manage. 48:165-171.

Heitschmidt, R.K., J.D. Volesky, M.R. Haferkamp, and P.O. Currie. 1993. Steer performance on native and mechanically modified Northern Great Plains rangeland. J. Range Manage. 46:529-533.

Hewlett, D.B., J.R. Johnson, R.I. Butterfield, and V.K. Mosley. 1981. Japanese brome response to atrazine in combination with nitrogen fertilizer in the mixed prairie. J. Range Manage. 34:22-25.

Kuchler, A. W. 1964. Potential natural vegetation of the conterminous United States. Amer. Geog. Soc. Spec. Pub. 36. Amer. Geog. Soc. New York, N.Y.

Mayland, H.F., R.B. Murray, and G.E. Shewmaker. 1994. Forage yields and quality trends of annual grasses in the Great Basin, p.387-391. In: S.B. Monsen and S.G. Kitchen (eds.) Proc. Ecology and management of annual rangelands. 18-21 May 1992. Boise, Ida., USDA-FS Gen. Tech. Rep. INTGTR 313. Ogden, Ut.
Rummell, R.S. 1946. Some effects of competition from cheatgrass brome on crested wheatgrass and bluestem wheatgrass. Ecol. 27:159-167.

SAS. 1990. SAS/STAT user's guide. Vol. 2, Version 6 (4th Ed.). SAS Inst. Inc. Cary, N.C. Technicon Industrial Systems. 1977. Digestion and sample preparation for the analysis of total Kjeldahl nitrogen/phosphorus using the Technicon BD-20 block digester. Technicon Autoanalyzer II Methodology. Industrial Method No. 369-75 A/B. Technicon Industrial Systems. Tarrytown, N.Y.

Tilley, J.M.A. and R.A. Terry. 1963. A twostage technique for the in vitro digestion of forage crops. J. Brit. Grassl. Soc. 18:104-111

Tipton, F.H. 1994. Cheatgrass, livestock, and rangeland, p.414-416. In: S.B. Monsen and S.G. Kitchen (eds.) Proc. Ecology and management of annual rangelands. 18-21 May 1992. Boise, Ida., USDA-FS Gen. Tech. Rep. INT-GTR 313. Ogden, Ut.
Vallentine, J.F. and A.R. Stevens. 1994. Use of livestock to control cheatgrass-a review, p.202-206. In: S.B. Monsen and S.G. Kitchen (eds.) Proc. Ecology and management of annual rangelands. 18-21 May 1992. Boise, Ida., USDA-FS Gen. Tech. Rep. INTGTR 313. Ogden, Ut.

Whisenant, S.G. 1990. Postfire population dynamics of Bromus japonicus. Amer. Midl. Natur. 123:301-308.

White, L.M., G.P. Hartman, and J.W. Bergman. 1981. In vitro digestibility, crude protein, and phosphorus content of straw of winter wheat, spring wheat, barley, and oat cultivars in eastern Montana. Agron. J. 73:117-121. 